\title{
Tilrettelegging for dybdelæring ved bruk av samarbeidslæring og hverandrevurdering - med 200 studenter.
}

\author{
L.H. Godager*, S.R. Sandve**, S. Fjellheim** \\ Norges milj $\phi$ - og biovitenskapelige universitet \\ * Fakultet for realfag og teknologi ** Fakultet for biovitenskap
}

\begin{abstract}
I denne artikkelen drøftes studentenes læringsutbytte og opplevelse av endret undervisningsform i grunnkurs i genetikk for 182 studenter, fra tradisjonell forelesning med utstrakt bruk av Power Point til mer studentaktiv undervisning. Det endrede undervisningsopplegget varte i fem uker, og vektla utvikling av omvendt undervisning, utarbeiding av begrepskart, samarbeidslæring, representasjoner/konkreter i læring, presentasjon av fagstoff for medstudenter samt hverandrevurdering. Studentenes læringsutbytte ble vurdert $i$ etterkant av disse fem ukene ved å gi studentene fjorårets eksamensspørsmål uten mulighet til forberedelser, mens studentenes opplevelse av undervisningsform ble målt med spørreundersøkelser og dybdeintervju. Resultatene våre viser at studentene som fikk undervisning som la vekt på studentenes aktive deltagelse og som fikk uforberedte eksamensspørsmål, presterte faglig like godt som tidligere studenter som hadde hatt tradisjonell undervisning og forberedt seg normalt til eksamen. Dette er en indikasjon på at studentaktiv læring gir en mer varig forståelse av begreper, metoder og sammenhenger i genetikkfaget, ofte referert til som dybdelæring (Utdanningsdirektoratet, 2019). I tillegg til fagkunnskap innen genetikk satt studentene igjen med en rekke andre ferdigheter, bl.a.: representasjons-, samarbeids-, presentasjons- og vurderingsferdigheter. Det overveldende flertall ga tilbakemelding på at de var motiverte for å lære seg fagstoffet, fornøyd med undervisningsformen og hadde fått nye venner, noe som viser at tiltaket også bidro til utvikling av det sosiale fellesskapet i emnet. Studentene var samtidig også tydelige på at samarbeidslæring er ressurskrevende og anbefaler samarbeidslæring kun i kortere perioder av et emne.
\end{abstract}

\section{MÅL}

Prosjektets målsetting var å teste ut ulike former for studentaktiv læring i kurs med mange studenter. Vi ville unders $\varnothing \mathrm{ke}$ om samarbeidslæring og hverandrevurdering ga $\varnothing \mathrm{kt}$ læringsutbytte, større grad av dybdelæring og $\varnothing \mathrm{kt}$ motivasjon for læring.

\section{INNLEDNING}

Studenter lærer mer når de er aktivt engasjert i egen læring enn de gjør i et passivt forelesningsmiljø. Omfattende forskning støtter denne observasjonen, spesielt innen realfag på universitet og høyskolenivå (Freeman et al., 2014). Dette var utgangspunktet da vi ønsket å endre undervisningsform for ca. 200 genetikkstudenter ved Norges miljø og biovitenskapelige universitet (NMBU). For å frigjøre tid til studentaktiv læring på campus, ble omvendt undervisning introdusert, slik at studentene skulle komme godt forberedt og få mest mulig utbytte av de studentaktive $\varnothing$ ktene de skulle arbeide seg gjennom (O'Flaherty \& Phillips, 2015). Et sentralt element i det endrede undervisningsopplegget videre, var samarbeidslæring, og her var grunntanken at studentene lærer bedre som en del av en gruppe enn som individ. Kjernen i samarbeidslæring er å oppnå et felles mål, og dette krever stor innsats fra gruppemedlemmene ut over faglig kompetanse (Aakervik, Haugaløkken, Johnson, \& Johnson, 2006). Den faglige læringen skulle foregå ved at gruppemedlemmene benyttet grunnleggende ferdigheter, spesielt muntlige ferdigheter, til å forklare for hverandre betydningen ulike begreper og diskutere mulige løsningsforslag for hvordan begrepene henger sammen (Wellington \& Osborne, 2001). For å legge til rette for begrepslæring og forståelse av modeller for biologiske prosesser, ble utarbeidelse av begrepskart (Hay, Kinchin, \& Lygo-Baker, 2008), modellbygging/representasjoner (Tytler, Prain, Hubber, \& Waldrip, 2013) og presentasjon av fagstoff for medstudenter (Stigmar, 2016) sentrale 
elementer i undervisningsopplegget. Et siste element vi ønsket å introdusere for $\emptyset \mathrm{kt}$ læringsutbytte var hverandrevurdering, en toveis og gjensidig type læring som er fordelaktig for begge parter (Boud, Cohen, \& Sampson, 2014).

\section{KONTEKST}

Grunnkurs i genetikk er et av de større grunnemnene på NMBU. Det inngår som et obligatorisk kurs i flere av studieprogrammene ved universitetet, gir 10 stp. og har i snitt ca. 200 studenter pr. kurs. Emnet har 2 ganger 2 timer undervisning i uken. Opprinnelig var kurset delt inn i tre deler, der en del var en kombinasjon av teori og laboratorieøvelser, en del en kombinasjon av teori og regneøvelser, mens en siste del hovedsakelig bestod av begrepstunge forelesninger. Det var denne siste begrepstunge delen, som også innebærer forståelse av modeller for biologiske prosesser, som ble endret mot mer studentaktive arbeidsmåter hos studentene med større grad av aktiviteter rettet mot faglig forståelse gjennom dybdelæring, enn mot pugg og overflatelæring slik det hadde vært tidligere. Da vi startet opp med grunnkurset i genetikk januar 2019, fikk alle de 190 studentene informasjon om det nye undervisningsopplegget som var planlagt gjennomført, og et tilbud om å delta. Kun 8 studenter takket nei til det nye undervisningsopplegget. Disse 8 studentene fikk tilbud om å se innspillinger av tidligere forelesning med utstrakt bruk av Power Point. De resterende 182 studentene $\emptyset$ nsket å delta i det nye undervisningsopplegget.

\section{METODE}

For best mulig utnyttelse av samarbeidslæring, ble de 182 studentene delt inn i hetrogene grupper på 45 studenter, slik at både studenter med lavt, middels og høyt prestasjonsnivå var på samme gruppe. Studenter i hetrogene grupper engasjerer seg oftere $\mathrm{i}$ å forklare for hverandre og tar oftere andres perspektiv når de diskuterer lærestoffet. I tillegg foregår det mer komplisert tenkning som øker forståelsen og nøyaktigheten på langtidsminnet (Aakervik, Haugaløkken, Johnson, \& Johnson, 2006). Studentene ble introdusert til teorier og øvelser i samarbeidslæring og vurdering i forkant av oppstart. Det var også viktig å motivere studentene til aktivt å ta del i dette endrede undervisningsopplegget, siden motivasjon hos studentene er sentralt for suksess med studentaktiv undervisning (Tharayil et al., 2018). Teorier om at studentaktiv undervisning, samarbeidslæring og hverandrevurdering gir $\emptyset \mathrm{kt}$ læringsutbytte, gir mer dybdelæring og gir variasjon og motivasjon til læring, ble introdusert for studentene (P Østern et al., 2019). For å kunne bistå de 40 gruppene i deres faglige og sosiale prosesser, ble 8 mentorer ansatt for å følge opp 5 grupper hver. Disse mentorene var alle studenter med bakgrunn i genetikk, og enkelte var også lektorstudenter.

Det endrede undervisningsopplegget varte i fem uker, der gruppene hver uke bearbeidet ulike temaer knyttet til ett eller to kapitler i læreboka. Hver av de fem ukene var identisk bygd opp. Studentene arbeidet seg gjennom 8 steg: 1) se inspirasjonsvideo om ukens tema, 2) lese om temaet, 3) beskrive begreper knyttet til tema, 4) lage felles begrepskart, 5) sammen lage representasjoner av modeller for biologiske prosesser knyttet til ukas tema, 6) sammen forberede en presentasjon av ukens oppgave, 7) to av gruppens medlemmer presentere ukas oppgave til en annen gruppe, og 8) de tre gjenværende medlemmene av gruppen skulle vurdere en annen gruppes presentasjon. Studentene arbeidet individuelt gjennom de tre første stegene, mens gruppemedlemmene samarbeidet om de fem neste stegene. Alle gruppene fikk hver uke utlevert ulike konkreter/rekvisitter som de kunne benytte til å lage representasjoner knyttet til ukas tema. Alternativt kunne gruppene være kreative og benytte egne rekvisitter til å lage representasjoner for best mulig å beskrive en modell eller prosess. Disse representasjonene skulle de så benytte i presentasjonen av ukas oppgave.

Emnet hadde opprinnelig en avsluttende flervalgseksamen inkludert alle de tre delene av kurset, vurdert med en felles bokstavkarakter. Vi valgte å gjennomføre hverandrevurdering som summativ vurdering for denne ene studentaktive undervisningsdelen som varte i 5 uker, som skulle utgjøre $25 \%$ av den totale karakteren. Studentene fikk dermed kun spørsmål fra de to andre delene av emnet på den avsluttende flervalgseksamen, og ikke spørsmål fra fagstoff som var bearbeidet disse 5 ukene. For å kunne vurdere studentene gjennom disse 5 ukene med vektlegging av studentaktiv undervisning, utarbeidet vi et poengsystem for karaktersetting. Studentene fikk ett poeng dersom de hadde beskrevet begrepene på læringsplattformen innen tidsfristen, og gruppen kunne dermed totalt få med seg 5 poeng for innlevering av definisjoner hver uke. Dette ble gjennomført for å motivere studentene til å stille forberedt til 
samarbeidsøkten, slik at læringsutbyttet ville bli best mulig (Buchs, Gilles, Antonietti, \& Butera, 2016). Gruppen kunne også få opptil 5 poeng for begrepskartet de hadde utarbeidet i fellesskap, 12 poeng for faglig innhold i presentasjonen, 2 poeng for form og presentasjon og 1 poeng for bruk av kreativitet $\mathrm{i}$ presentasjonene sine. Totalt kunne gruppen få 25 poeng per uke for begrepsinnlevering, begrepskart og presentasjon. Poengsummen gruppen fikk etter 5 uker med studentaktiv undervisning ble omregnet av emneansvarlig til en felles karakter som hver av gruppemedlemmene fikk.

\section{RESULTAT}

For å evaluere studentenes læringsutbytte i etterkant av disse fem ukene, ble studentenes fagkunnskap testet ved å gi dem eksamensspørsmål for det aktuelle fagstoffet fra året før. Studentene ble ikke informert om dette på forhånd, så de hadde ikke hatt mulighet til å forberede seg. Studentene med studentaktiv undervisning presterte like godt på eksamensspørsmålene uten forberedelser, som de som hadde gjennomført en standard undervisning og eksamen året før.

De 182 studentene som hadde deltatt i det endrede opplegget, besvarte et omfattende spørreskjema der de ble bedt om å beskrive hvor fornøyd de var med de ulike øktene, vurdere eget læringsutbytte ved hver $\varnothing \mathrm{kt}$, beskrive hva som var bra/dårlig, forslag til forbedringer og hva de syntes var veldig bra med dette studentaktive opplegget. 78\% av studentene var svært godt eller godt fornøyd med sin totalopplevelse av ukene med studentaktiv læring, og bare $9 \%$ sa de ikke ville valgt å bli med på denne $\emptyset \mathrm{kten}$ dersom de fikk velge på nytt. $66 \%$ sier de med sikkerhet vil anbefale samarbeidslæring til andre emneansvarlige ved universitetet, kun $11 \%$ vil fraråde dette.

Tilbakemeldingene til inspirasjonsvideoene og begrepsinnlevering var i stor grad positive. Svært mange studenter var spesielt fornøyd med utarbeidelse av begrepskart og hele $77 \%$ vurderer eget læringsutbytte som godt eller svært godt ved bruk av dette. Bruk av rekvisitter til modeller og presentasjoner hadde en blandet mottagelse. Halvparten av studentene var veldig positive og engasjerte i dette og opplevede $\varnothing \mathrm{kt}$ læringsutbytte, mens den andre halvparten ikke var like positive. Et flertall av studentene skriver i tilbakemeldingene at de opplevde et større læringsutbytte med samarbeidslæring og hverandrevurdering, enn det de opplever med tradisjonell forelesning og peker i tillegg på et bedre studentmiljø med nye venner som resultat av samarbeidslæring. Studentene var samtidig også tydelige på at samarbeidslæring er ressurskrevende og anbefaler samarbeidslæring kun i kortere perioder av et emne.

\section{REFLEKSJON}

Vi hadde som mål med denne studentaktive undervisningen å $\varnothing$ ke læringsutbytte, tilrettelegge for aktiviteter som stimulerer til dybdelæring og øke læringsmotivasjonen til studentene. Studentene ble spurt om å vurdere eget læringsutbytte, og selv om hele 77\% vurderer eget læringsutbytte som godt eller svært godt ved bruk av dette undervisningsopplegget, er det vist at følelsen av læring sammenlignet med faktisk læring ikke alltid stemmer overens (Deslauriers, McCarty, Miller, Callaghan, \& Kestin, 2019). Deslauriers mfl. viser at faktisk læring ofte er større enn følelsen av læring når studentene er aktivt engasjert i egen læring. Motstand fra studenter til å aktivt ta del i egen læring er ofte en grunn til at en tredjedel av foreleserne som tester ut studentaktiv læring returnerer til tradisjonelle forelesninger (Henderson, Dancy, \& Niewiadomska-Bugaj, 2012).

Studentene med studentaktiv undervisning presterte like godt på eksamensspørsmålene helt uten forberedelser, som de som året før hadde jobbet tradisjonelt med individuelt arbeid der vi erfaringsmessig vet at studentene pugger til eksamen. Dette resultatet kan tyde på at samarbeidslæringen vi gjennomførte ga dybdelæring. Øyehaug (s.39, (Voll, Øyehaug, \& Holt, 2019)) beskriver i boken om dybdelæring at «for å oppnå dybdelæring i naturfag må elever få tilgang til de begreper og modeller som er etablert i naturvitenskapen. Lærer introduserer sentrale begreper og modeller, og elevene må få anledningen til å anvende disse mens de lærer» (Voll et al., 2019). Sentralt i dette opplegget var nettopp bearbeiding av begreper og lage egne modeller av de begreper og prosesser som var aktuelle. En student skriver:

«Fфler det var litt sånn trappelaering. Forstod ikke så mye av begrepsinnleveringen, litt mer av begrepskarter, og mye av fremforing. Men tror de alle i ett var viktige for å få med seg de små tingene. Jeg var svart heldig med gruppa som har vart over gjennomsnittet arbeidssom, og vi har fătt en veldig god tone. Dette er en metode jeg kanskje kommer til å bruke frivillig $i$ andre fag også. Det er 
arbeidskrevende, men jeg merker at det blir en annen type laring som skaper mer motivasjon. Det var selve de konkretene vi lagde selv som fungerte best for laringen egentlig. Bestod i hovedsak mest av utklipte figurer i papir, og tegninger. Jeg syntes også at inspirasjonsvideoene var veldig nyttige der foreleser pratet selv. Forn $\phi y d$ med mentoren!»

Mange var svært fornøyd med samarbeidet i gruppa, men ikke alle 40 gruppene hadde et like godt samarbeid. For at en gruppe skal samarbeide godt, er det fem elementer som alle må være oppfylt: gjensidig positiv avhengighet mellom gruppemedlemmene, individuell ansvarlighet, utviklingsfremmende ansikt - til ansikt interaksjon, sosiale ferdigheter og evaluering av læringsprosessen. (D. W. Johnson \& Johnson, 1989). Gjennom samarbeidslæring i det endrede undervisningsopplegget ble studentene gjort ansvarlig for sin egen og gruppas læring ved at de alle hadde ansvar for individuell begrepsinnlevering, et felles begrepskart, felles representasjoner og en felles presentasjon som ble vurdert med en felles karakter. Gruppemedlemmene ble ansvarliggjort ved at de hadde ulike roller og oppgaver underveis, der de andre i gruppa var avhengig av at hver enkelt utførte sin oppgave. Likevel var det noen studenter som sviktet sitt individuelle ansvar og ikke bidro like mye inn i samarbeidet, slik at andre måtte bidra med en større del. Studentene ble oppfordret til å løse utfordringene de møtte i gruppen innad med hverandre, for slik å øve sosiale samarbeidsferdigheter.

Med utgangspunkt i vurderingskriterier skulle studentene vurdere og reflektere over andre studenters presentasjon og gi poeng på faglig innhold, kreativitet og formen på presentasjonen. $46 \%$ av studentene vurderte eget læringsutbytte av å vurdere medstudenter som godt eller svært godt. Målet med hverandrevurdering er å fremme læring, men kan i tillegg være et godt alternativ til lærerevaluering i fag med mange studenter. Hverandrevurdering har vist seg å gi gode resultater ved høyere utdanning i Norge (Burner, Baraas, \& Falkenberg, 2011). Vurderinger av hva man husker, hvilke kunnskaper og kognitive ferdigheter en har, sorterer under begrepet metakognisjon. Forskning knyttet til dette området indikerer at mange studenter ofte er usikre på hva de har lært eller kan (Dunlosky \& Metcalfe, 2008). Reelt læringsutbytte kan derfor avvike fra studentens egenvurdering av opplevd læringsutbytte.

Studentaktiv undervisning med så store grupper som i dette prosjektet (opp mot 200 studenter) kan kreve ekstra ressurser. Vi ansatte mentorer til veiledning av gruppene og benyttet ekstra rom til arbeid i grupper. På den annen side var hverandrevurderingen til en viss grad ressursbesparende. En viktig suksessfaktor for oss var også at vi hadde satt av god tid i forkant av oppstart til å diskutere og forberede for gjennomføring av det studentaktive undervisningsopplegget.

\section{OPPSUMMERING}

Funnene fra studien tyder på at de 8 stegene i vår undervisningsmodell over 5 uker bidro til at studentene har lært mer enn ved tradisjonell forelesning. Studentene har fått tilsvarende faglig læringsutbytte på sluttvurderingen, samtidig fremhever de at de har fått $\varnothing \mathrm{kt}$ motivasjon og utviklet læringsmetoder i faget som de ønsker å ta i bruk i videre studier. Studentene har fătt erfaring med omvendt undervisning, utarbeidelse av begrepskart, lage gode representasjoner av modeller og prosesser, forberede presentasjon, undervise for medstudenter, vurdere medstudenter og samarbeidsferdigheter. Videre viser prosjektet at studentene har blitt sosialisert på en bedre måte gjennom vårt opplegg og dette bekrefter de ved glede over å ha fătt nye venner.

\section{REFERENCES}

Aakervik, A., Haugaløkken, O., Johnson, R., \& Johnson, D. (2006). Samarbeid i skolen: pedagogisk utviklingsamspill mellom mennesker (4. rev. utg. ed.). Namsos: Pedagogisk psykologisk forlag.

Boud, D., Cohen, R., \& Sampson, J. (2014). Peer learning in higher education: Learning from and with each other: Routledge.

Buchs, C., Gilles, I., Antonietti, J.-P., \& Butera, F. (2016). Why students need to be prepared to cooperate: a cooperative nudge in statistics learning at university. Educational Psychology, 36(5), 956-974.

Burner, T., Baraas, R. C., \& Falkenberg, H. K. (2011). Studentaktive vurderingsformer i norsk lærer-og optometriutdanning. Uniped, 34(01), 44-57.

Deslauriers, L., McCarty, L. S., Miller, K., Callaghan, K., \& Kestin, G. (2019). Measuring actual learning versus feeling of learning in response to being actively engaged in the classroom. Proceedings of the National Academy of Sciences, 116(39), 19251-19257. 
Dunlosky, J., \& Metcalfe, J. (2008). Metacognition: Sage Publications.

Freeman, S., Eddy, S. L., McDonough, M., Smith, M. K., Okoroafor, N., Jordt, H., \& Wenderoth, M. P. (2014). Active learning increases student performance in science, engineering, and mathematics. Proceedings of the National Academy of Sciences, 111(23), 8410-8415.

Hay, D., Kinchin, I., \& Lygo-Baker, S. (2008). Making learning visible: the role of concept mapping in higher education. Studies in Higher Education, 33(3), 295-311.

Henderson, C., Dancy, M., \& Niewiadomska-Bugaj, M. (2012). Use of research-based instructional strategies in introductory physics: Where do faculty leave the innovation-decision process? Physical Review Special Topics-Physics Education Research, 8(2), 020104.

Johnson, D. W., \& Johnson, R. T. (1989). Cooperation and competition: Theory and research: Interaction Book Company.

O'Flaherty, J., \& Phillips, C. (2015). The use of flipped classrooms in higher education: A scoping review. The internet and higher education, 25, 85-95.

P Østern, T., Dahl, T., Strømme, A., Aagard Petersen, J., Østern, A.-L., \& Selander, S. (2019). Dybde//Læring: en flerfaglig, reasjonell og skapende tilnærming: Universitetsforlaget.

Stigmar, M. (2016). Peer-to-peer teaching in higher education: A critical literature review. Mentoring \& Tutoring: partnership in learning, 24(2), 124-136.

Tharayil, S., Borrego, M., Prince, M., Nguyen, K. A., Shekhar, P., Finelli, C. J., \& Waters, C. (2018). Strategies to mitigate student resistance to active learning. International Journal of STEM Education, 5(1), 7.

Tytler, R., Prain, V., Hubber, P., \& Waldrip, B. (2013). Constructing representations to learn in science: Springer Science \& Business Media.

Utdanningsdirektoratet. (2019). Retrieved from https://www.udir.no/laring-og-trivsel/dybdelaring/

Voll, L., Øyehaug, A., \& Holt, A. (2019). Dybdelæring i naturfag. Dybdelæring i naturfag, 17-37.

Wellington, J., \& Osborne, J. (2001). Language and literacy in science education: McGraw-Hill Education (UK). 